\title{
Towards a sustainable human use of freshwater crayfish (Crustacea, Decapoda, Astacidea)
}

\author{
F. Gherardi ${ }^{(1)}$ \\ Received January 11, 2011 \\ Revised April 3, 2011 \\ Accepted April 21, 2011
}

\section{ABSTRACT}

Key-words: direct and indirect uses, surrogate species, option values, existence and bequest values, Crustacea Decapoda Astacidea
To face the severe loss in biodiversity recorded in freshwater crayfish (Crustacea, Decapoda, Astacidea), there is an increasing awareness that the CBD's concept of the sustainable use of natural resources should be applied also to this large assemblage of species. This review paper will synthesize the several uses we make or have made of crayfish with the purpose of pinpointing where sustainability is desirable and feasible. Uses are here classified as direct (i.e. consumption and production) and indirect. The latter uses refer to the recreational, cultural, ethical, aesthetic, scientific and education values of crayfish. An additional indirect use regards the environmental key role this taxon plays. Several examples, mostly related to Europe, will be provided to illustrate the importance of crayfish to human societies, culture and history. The potential of assigning a non-use value to them will be finally discussed.

\section{RÉSUMÉ}

\section{Vers un usage durable des écrevisses d'eau douce (Crustacea, Decapoda, Astacidea)}

Mots-clés :
usages
directs et
indirects,
espèces de
substitution,
valeurs
d'options,
valeurs
d'existence
et de legs,
Crustacea
Decapoda
Astacidea

Mots-clés :

Pour faire face à la perte de biodiversité enregistrée pour les écrevisses d'eau douce (Crustacea, Decapoda, Astacidea), il y a une prise de conscience accrue que le concept de bioconservation (CBD) pour l'emploi durable des ressources naturelles devrait s'appliquer à ce large assemblage d'espèces. Cette revue veut synthétiser les nombreux usages que nous faisons ou avons faits des écrevisses avec le but de mettre le doigt sur les cas où la durabilité est souhaitable et faisable. Les usages sont classés ici en directs (i.e. consommation et élevage) et indirects. Ces derniers usages concernent la valeur récréative, culturelle, éthique, esthétique, scientifique et éducative des écrevisses. Un usage supplémentaire indirect concerne le rôle environnemental clé que ce taxon joue. Plusieurs exemples, la plupart pris en Europe, sont cités pour illustrer l'importance des écrevisses pour les sociétés humaines, leur culture et leur histoire. La possibilité de leur attribuer une valeur de non-usage est finalement discutée.

(1) Dipartimento di Biologia Evoluzionistica "Leo Pardi”, Università degli Studi di Firenze, Via Romana 17, 50125 Firenze, Italy, francesca.gherardi@unifi.it 


\section{INTRODUCTION}

"We need a new vision of biological diversity for a healthy planet and a sustainable future for humankind." (The United Nations Secretary-General Ban Ki-moon, 2010)

The principle of sustainable use of biodiversity is formalized in Article 10 of the 1993 Convention of Biological Diversity (http://www.cbd.int/convention/), which declares that, among other actions, each Contracting Party shall "integrate consideration of the conservation and sustainable use of biological resources into national decision-making"; "adopt measures relating to the use of biological resources to avoid or minimize adverse impacts on biological diversity"; and "protect and encourage customary use of biological resources in accordance with traditional cultural practices that are compatible with conservation or sustainable use requirements". A broad definition of "sustainable use" appears in Article 2 of CBD as "the use of components of biological diversity in a way and at a rate that does not lead to the long-term decline of biological diversity, thereby maintaining its potential to meet the needs and aspirations of present and future generations." In a more recent document, "The Addis Ababa principles and guidelines for the sustainable use of biodiversity" (2004), sustainable use is deemed to be "a valuable tool to promote conservation of biological diversity, since in many instances it provides incentives for conservation and restoration because of the social, cultural and economic benefits that people derive from that use" (http://www.cbd. int/sustainable/addis.shtml). Specifically, "sustainable use management goals and practices should avoid or minimize adverse impacts on ecosystem services, structure and functions as well as other components of ecosystems" (practical principle 5); "interdisciplinary research into all aspects of the use and conservation of biological diversity should be promoted and supported" (practical principle 6); and "education and public awareness programs on conservation and sustainable use should be implemented and more effective methods of communications should be developed between and among stakeholders and managers" (practical principle 14).

As a result of the growing interest for the conservation of freshwater crayfish (Crustacea, Decapoda, Astacidea), there is an increasing awareness among various stakeholders that the CBD's concept of sustainable use of biodiversity and the Addis Ababa's practical principles should be also applied to this large assemblage of species. Robust evidence show that crayfish global diversity is subject to many threats and that the anthropogenic drivers of their diversity loss will intensify: in the 2010 Global IUCN Red List Assessment, out of the 569 crayfish species assessed, about $25 \%$ have been classified as threatened in some way, including four species deemed as extinct (IUCN - Freshwater Crab and Crayfish Specialist Group, unpublished data). On the other hand, crayfish are key components of biodiversity in lakes, rivers and wetlands, their ecological role being crucial for the appropriate functioning of all freshwater ecosystems they inhabit. Their removal from or addition to a community may lead to cascading effects down the food web, with the consequences that the services that ecosystems offer to humankind will be altered and human wellbeing will be ultimately affected.

As opposed to these views, for many people the term crayfish conjures up images of feasts and laid tables: they are a luxury food which commands a high price, particularly in western markets, and demands for increased production. An analysis of the data published online by the Fishery and Aquaculture Department of the Food and Agricultural Organization of the United Nations (http://www.fao.org/fishery/statistics/en) clearly shows a sharp increase since 2000 in the global production of freshwater crayfish with values exceeding $400000 \mathrm{t}$ in 2008 (Figure 1). This increase is exclusively due to the boom in the production of the red swamp crayfish Procambarus clarkii (Girard) in the People's Republic of China, to which this species was first introduced in the 1930s: since 2002, Chinese production has even exceeded that of the USA (Huner, 2002), reaching $364619 \mathrm{t}$ in the sole 2008. On the contrary, the world's capture production has remained nearly constant since 1970, averaging about 9500 t per annum. There is no doubt that the use of crayfish as food is important for some countries and sectors of society, but human consumption is not the unique - and possibly not the most 


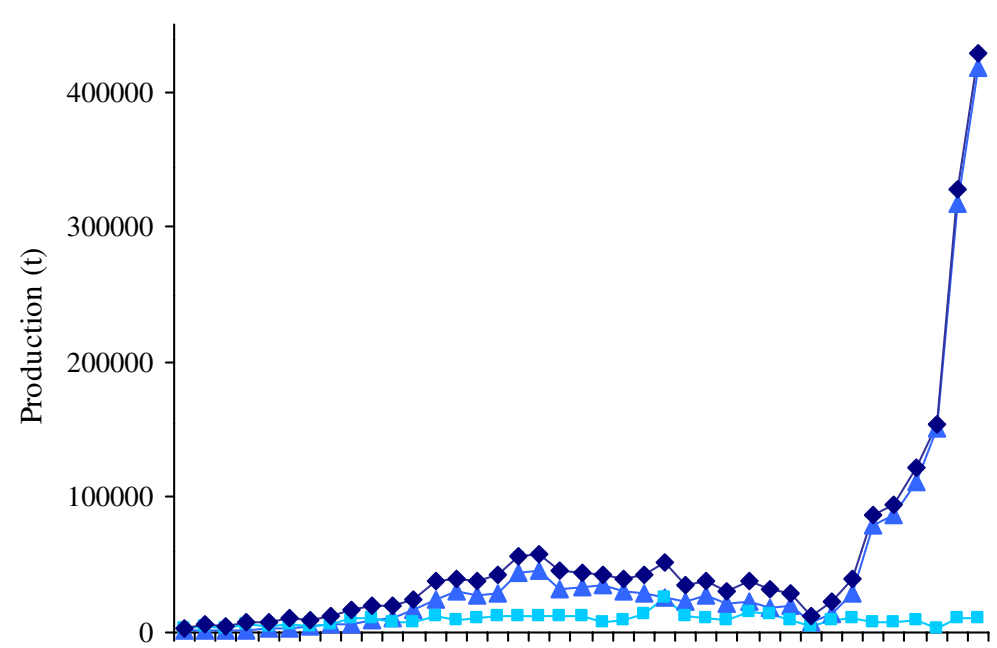

$\begin{array}{llllllllllllllllllll}70 & 72 & 74 & 76 & 78 & 80 & 82 & 84 & 86 & 88 & 90 & 92 & 94 & 96 & 98 & 00 & 02 & 04 & 06 & 08\end{array}$

$$
\neg \text { Aquaculture } \longrightarrow-\text { Capture } \longrightarrow \text { Total }
$$

\section{Figure 1}

Global production of crayfish in the period 1970-2008, compared between aquaculture and capture productions. Aquaculture production relates to: Astacus astacus, Astacus leptodactylus, Cherax destructor, Cherax quadricarinatus, Cherax tenuimanus, Pacifastacus leniusculus, Procambarus clarkii and other unspecified North American Cambaridae. Capture production relates to: Astacus astacus, Austropotamobius pallipes, Cherax destructor, Cherax quadricarinatus, Euastacus armatus, Pacifastacus leniusculus, Procambarus clarkii and other unspecified North American Cambaridae and Oceanian Parastacidae.

\footnotetext{
Figure 1

Production globale d'écrevisses de 1970 à 2008, comparant les productions d'aquaculture et de pêche. La production aquacole concerne : Astacus astacus, Astacus leptodactylus, Cherax destructor, Cherax quadricarinatus, Cherax tenuimanus, Pacifastacus leniusculus, Procambarus clarkii et d'autres cambaridés nord-américains. La production halieutique concerne : Astacus astacus, Austropotamobius pallipes, Cherax destructor, Cherax quadricarinatus, Euastacus armatus, Pacifastacus leniusculus, Procambarus clarkii et d'autres cambaridés nord-américains et des parastacidés océaniens.
}

important - use we make of them. Indeed, only a tiny fraction of the over 640 crayfish species described so far (Crandall and Buhay, 2008) occurs in the market. These include: P. clarkii, the white river crayfish (Procambarus acutus (Girard) and Procambarus zonangulus Hobbs and Hobbs), the signal crayfish Pacifastacus leniusculus (Dana), the noble crayfish Astacus astacus (Linnaeus) and the narrow-clawed crayfish Astacus leptodactylus Eschscholtz. To these, Australian species of the genus Cherax are to be added: the destructor group (the yabbies) with Cherax albidus Clark and Cherax destructor Clark, the red claw Cherax quadricarinatus (Von Martens) and the marron Cherax tenuimanus Smith. Other species with some potentials of entering the market include the North American Cambarus robustus Girard (Guiaşu, 2002), the spiny-cheek crayfish Orconectes limosus (Rafinesque), the rusty crayfish Orconectes rusticus (Girard) and the virile crayfish Orconectes virilis (Hagen) (Hamr, 2002), as well as the Australian koonac Cherax plebejus Hess, gilgies Cherax glaber Riek and the Murray crayfish Euastacus armatus (Von Martens).

This review will analyze the various uses we make of crayfish following the scheme shown in Figure 2. Uses are here classified as direct and indirect. Direct uses are associated with consumption and production: consumption relates to crayfish being harvested and consumed directly, often at a local scale, while production refers to the product being sold in national and international markets. Indirect uses are related to the recreational values of crayfish, along with their cultural, ethical, aesthetic, scientific and education values. An additional indirect 

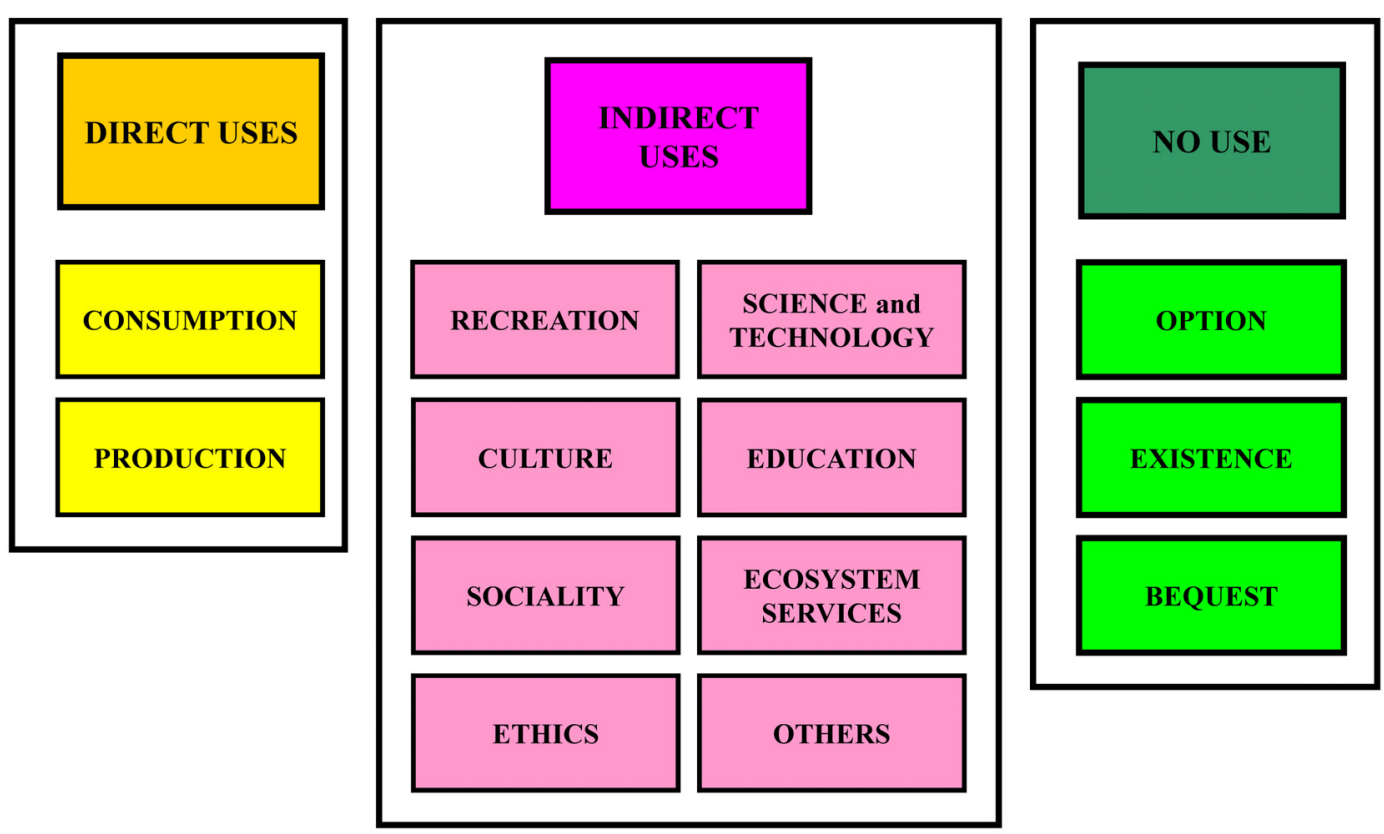

\section{Figure 2}

Scheme synthesizing the uses we make of crayfish, distinguished between direct and indirect uses and non-use values.

\section{Figure 2}

Schéma synthétisant les usages faits des écrevisses, distinguant usages directs et indirects, valeurs d'usage et de non-usage.

use regards the environmental key role played by crayfish, a role that assures the correct functioning of ecosystems and the services they provide. Several examples, mostly related to Europe, will be provided here to illustrate the importance of this taxon to human societies, culture and history. The potential of assigning a value to crayfish for not using them will be finally discussed.

\section{CONSUMPTION}

"We have always collected crayfish; it is our tradition." (Elder in the village of Vohiparara, Ranomafana National Park, Madagascar; after Jones, 2004)

The most obvious use of crayfish is human consumption. As shown by Tricarico et al. (2008), the abdominal muscle of $P$. clarkii has good nutritional qualities that are kept nearly constant during at least 21 days of stabulation at an ad libitum or restricted feeding regime. Crayfish muscles are characterized by high levels of proteins (reaching $13.24 \%$ on dry matter) and low levels of lipids (less than $0.8 \%$ on dry matter). Particularly abundant are fatty acids containing long-chains of n3 PUFAs, such as EPA (C20:5n3) and DHA (C22:6n3) (Buckup et al., 2008), which are both highly appreciated by the consumers because they prevent cardiovascular pathologies (e.g. Thies et al., 2003).

The quality value of crayfish meat was also known in the Medieval times, as illustrated in Theatrum Sanitatis, a treatise on medicine authored by Ububchasym of Baldach, a Christian physician, in 1052-1063. One of its pages features a miniature showing one of the first crayfish parties ever represented in the human history (Figure 3).

Crayfish constitute a gourmet food but little is known about their current consumptive use, i.e. their use as a subsistence diet at a local scale. In Australia, crayfish fragments and gastroliths have been found in aboriginal cooking hearths some 28000 years old (Holdich, 2002). 


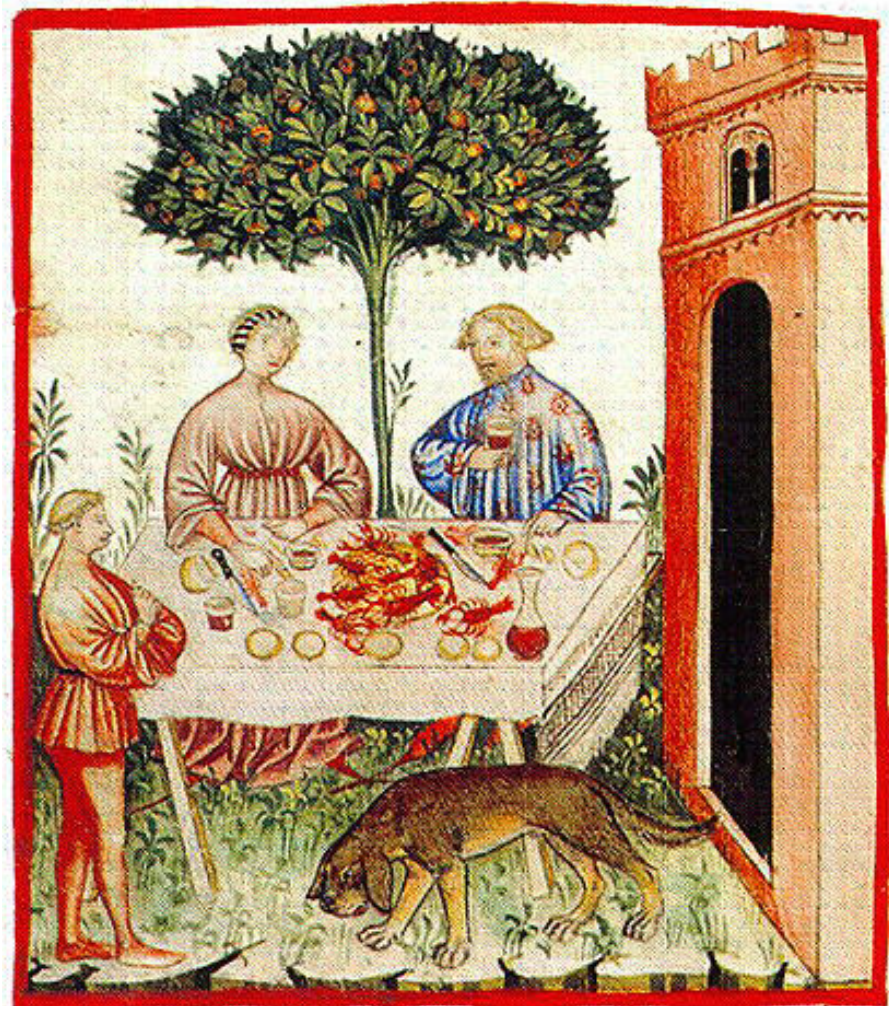

\section{Figure 3}

A miniature from the medical treatise Theatrum Sanitatis representing a crayfish party. The treatise was written by Ububchasym of Baldach, a Christian physician, in 1052-1063, but the miniatures are attributed to the Lombard school of the second half of the XIVth century.

\section{Figure 3}

Une miniature d'un traité de médecine, Theatrum Sanitatis, représentant un repas d'écrevisses. Ce traité a été écrit par Ububchasym de Baldach, un physicien chrétien, en 1052-1063, mais les miniatures sont attribuées à l'école lombarde de la seconde moitié du XIVe siècle.

The aboriginal inhabitants of North America used to exploit crayfish stocks, although their large-scale exploitation started with the arrival of the Europeans (particularly French and Swedish immigrants) in North America (Holdich, 2002). Today, in some regions of PapuaNew Guinea (Wissel Lakes area of West Irian, the Ajamura region, Sentani Lake, the Nimboran Plain, and the Merauke River), crayfish are the only source of animal proteins along with pigs (Holdich, 2002). They are mostly fished by women with baited sink nets and hand nets; they are kept alive in woven bags until consumed and eaten by roasting in hot ashes. In New Zealand, the Māori have developed an original method to catch koura (= Paranephrops planifrons White), the tau koura, which consists in placing whakaweku (= bundles of bracken fern Pteridium esculentum (G. Forst.) Cockayne) on the lake bed that koura readily colonize (Kusabs and Quinn, 2009).

A study by Jones (2004) on the exploitation of four species of the Astacoides genus in Ranomafana National Park (Madagascar) showed that more than 50\% of the 47 households in the village Vohiparara are directly involved in harvesting Astacoides granulimanus Monod and Petit (called by the locals Orambato). However, less than $6 \%$ of the harvest is consumed by the villagers, although crayfish contribution to providing proteins to the young is relevant (Jones et al., 2006). Most harvested crayfish are sold to passers-by or to stallholders. Revenues from crayfish are important for local people. The mean annual earning from crayfish harvesting in the years 2003-2004 was US\$82, leading to a gross annual revenue of US $\$ 2074$ for the harvesters from the village of Vohiparara. Since rural households in the area 
live on less than US $\$ 170$ a year, harvesters in Vohiparara earn between 12.4 and $145 \%$ of this amount from crayfish harvesting (Jones, 2004). The number of the collected crayfish is particularly high (up to 50000 crayfish in the years 2003-2004), which raises the question of whether crayfish harvesting is sustainable. The sustainability of crayfish harvesting was quantified by Jones (2004) by comparing population structure and density under varying harvesting intensity and using population models to investigate the forest area necessary to provide the observed annual harvest. The results showed that $A$. granulimanus harvest in the Ranomafana area may be sustainable under current conditions, whereas habitat loss and invasive species are a more immediate threat. It is interesting to note that there are several villages where local taboos (fady) prevent from commercial harvesting of crayfish. To the question of whether the belief of taboos demonstrates a concern about the status of that resource, interviews with locals in fady areas showed that crayfish are not viewed as limited resources. On the contrary, the recorded answers indicated a more utilitarian reasoning, that is: if men spend their time collecting and selling forest products, they may come back home with money, but one "can't eat money" (Jones, 2004).

The cultural history of consuming crayfish in Europe has been recently told by Swahn (2004). In ancient times even the Romans did not consider crayfish as a delicacy mostly because, being "scavengers", they belong to the denigrated category of animals that feed on carrion. Indeed, recipes of crustaceans in Roman cookery books mainly referred to the clawed lobsters and the scampi. During the Middle Ages, first in ex-Celtic France and later in England, crayfish started to be appreciated in gastronomy. Particularly in monasteries there was a large consumption of them during Lent: monks had in fact extended the concept of fish to crustaceans, beavers, seals and whales. Due to the appreciation of their meat, monks have been responsible for many crayfish translocations, including the translocation of Austropotamobius pallipes (Lereboullet) from France to Ireland (Gouin et al., 2003). From the monasteries the pleasure to eat crayfish spread to wider circles in medieval Germany. In the XVth century, crayfish dishes were very common in the upper class dinners. In Scandinavia, the use of crayfish as a gourmet seems to have been introduced by Christina of Saxony (1461-1521), queen consort of Denmark, Norway and Sweden, who got a delivery of crayfish from Lübeck (Germany) in 1504. In the XVIth century, crayfish were a gourmet food within aristocracy and rich townspeople although still many people disliked them. Carl von Linné, for instance, classified crayfish as insects and thus, as stated in Diaeta Naturalis (1733), unsuitable as food. However, from his writings it appears that this disgust was mainly due to allergy to shellfish. Other reasons of dislike are the observance to religious rules about diet; a passage of the Book of Leviticus (Leviticus 11) says: "of all the things that live in the water, you may eat these: anything in the water that has fins and scales, whether in seas or in rivers - these you may eat. But everything in the seas and rivers without both fins and scales, of all the small water-creatures and of all the living creatures in the water, is a detestable thing for you". Swedes from middle classes have started eating crayfish since the mid XIXth century but only in the XXth century did crayfish become a national delicacy: since then, people of all sectors of society have begun to celebrate kräftskiva, a feast that marks the end of summer.

\section{PRODUCTION}

"The importance of biodiversity is to be questioned when a commodity appears in its place." (Kaufman, 1992)

\section{> OVEREXPLOITATION OF THE INDIGENOUS STOCKS}

In the past, there are several reports of exaggerated consumption of crayfish. In 1386, during the wedding between the Polish Queen Jadwiga and Jogaila of Lithuania, 75000 crayfish were eaten in eight days. At the beginning of the XVIth century, over 30000 crayfish per year could be consumed at the monastery of Tegernsee (Bavaria). In Paris, during the second half of the XIXth century, more than 5 million crayfish per year were consumed. The increased 
consumption of crayfish, associated with the economic interest behind it, inevitably led to their overharvesting and poaching that, along with the spread, since 1860, of the crayfish plague, caused the crash of the available stocks.

This is well illustrated by a report written by Prof. Decio Vinciguerra (1899), in which he lamented the high consumption of crayfish in the Italian provinces of Belluno, Sondrio, Como, Aquila, Perugia and Salerno, the harvesting of $>100 \mathrm{~kg}$ per day per stream in Abruzzo and Umbria regions, the export of large quantities of Italian crayfish to the French markets, and the shrinking of populations due to the plague. He even suggested the introduction of Cambarus cambarus (i.e. P. clarkii) from the USA because of its "valuable quality" of being resistant to the disease.

Vinciguerra's report reflects a well-known phenomenon occurring in Europe. Before the onset of the crayfish plague in the mid 1800s, Western Europe was self-sufficient in crayfish production, the harvest being based mainly on $A$. astacus and $A$. pallipes, and countries such as Finland (Westman, 1991) and Sweden (Gydemo, 1989) were exporters. After the demise of much of the native stocks, crayfish supply was first shifted to $A$. astacus imported from the Baltic, Russia and Finland (Skurdal and Taugbøl, 2002), then to A. leptodactylus, harvested in Turkey and largely exported to Western Europe until 1986 (nearly $8000 \mathrm{t}$ in 1984) (Köksal, 1988). However, like the other astacids, A. leptodactylus is susceptible to the crayfish plague and many introductions were not successful. Turkey remained the main supplier of crayfish to Western Europe until a plague struck in 1985. Due to overfishing and plague, production dropped dramatically in 1986 and crayfish prices rose in Western Europe. After the successful introduction of $O$. limosus to Germany in 1890, the attention was directed to plague-resistant North American species, specifically P. leniusculus and $P$. clarkii, first introduced in the 1960s to northern Europe (Taugbøl and Johnsen, 2006) and in the 1970s to southern Europe (Gherardi, 2006), respectively.

A commercial consequence of the successful introductions of North American species was that $A$. astacus comprises only $2-3 \%$ of the total European annual catch, at least in 1999 (7000-8000 t; cf. Skurdal and Taugbøl, 2002), and 27\% of the total annual aquaculture production (about $160 \mathrm{t}$ ) in Europe (Ackefors, 1999), whereas the most abundantly harvested and farmed crayfish is $P$. clarkii. The noble crayfish, however, constitutes $10-20 \%$ of the value of the total crayfish harvest. For example, in Sweden, consumers are willing to pay higher prices for the indigenous rather than for non-indigenous species (Holdich, 1999): in 2010, the cost of freshly boiled $A$. astacus $\left(60-80 € \cdot \mathrm{kg}^{-1}\right.$ ) doubles the cost of freshly boiled $P$. leniusculus $\left(25-40 € \mathrm{~kg}^{-1}\right)$ and can be 10 times higher than the cost of imported frozen $P$. clarkii from China $\left(8-15 € \cdot \mathrm{kg}^{-1}\right)$ (L. Edsman, pers. comm.). In Finland $P$. leniusculus is even cheaper than in Sweden, reaching the maximum cost of 15-16 € $\mathrm{kg}^{-1}$ (J. Jussila, pers. comm.), whereas in Norway, harvest of $P$. leniusculus is still illegal, notwithstanding the presence of an established population (S.I. Johnsen, pers. comm.).

Certainly, the introduction of $P$. clarkii to Spain and the development of astaciculture have contributed to re-vitalizing the economy of some depressed regions by intensifying trade between Spain and the rest of Europe (Ackefors, 1999), and, since 2000, between Spain and the USA. This is however an isolated case: most often, the aims of offering economic benefits to local people by introducing non-indigenous crayfish species led to a miserable "flop". In the mid-1970s, P. leniusculus was introduced to Britain, mainly from Sweden, to test its aquaculture potential. It grew well, particularly in southern parts, and was distributed to many potential crayfish farmers, mainly for pond culture, although some were introduced into the wild. The British Crayfish Marketing Association (BCMA) was set up which helped maintain prices and quality, and marketed crayfish for its members. However, despite many predictions being made about the likely profits, they are still an unfulfilled promise: the BCMA did not survive for long as independent crayfish growers undercut their prices, and most of the exports are now being made with crayfish harvested from natural waters (Holdich, 1993). In Italy, the red swamp crayfish has been exploited in the Massaciuccoli Lake (Tuscany) since the 1990s, but this industry has met with very little success due to low demand of crayfish in the Italian markets (Barbaresi and Gherardi, 2000). In Africa, very few of the several 
projects that led to crayfish importations since the 1960s have been successful (Gherardi, 2007): in Lake Naivasha (Kenya), for example, crayfish supported commercial catches and their export at the beginning of its invasion, whereas today their harvest is limited to less than 40 metric t per year. Procambarus clarkii is offered to international tourists (Harper et al., 1990 ) but is rarely consumed by local people as it is viewed as an "insect" or a "red scorpion" (Gherardi et al., to appear). The ban posed on crayfish exports to Europe in 1983 due to concerns on cholera led to a significant drop in commercial crayfish exploitation, which is today nearly unproductive.

The above examples thus indicate that production of non-indigenous species is not a sustainable activity, also because the inevitable escapes from crayfish farms and deliberate introductions into the wild have led to self-sustaining populations of non-indigenous crayfish and their spread, with dramatic consequences for the integrity of the invaded ecosystems and the services they offer to humans (Gherardi, 2007). On the one hand, wild populations of nonindigenous crayfish may inflict direct costs to the society. The extensive burrowing of $P$. clarkii is a problem in agricultural fields, such as rice cultures, and in lawns, golf courses, levees, dams, dykes, rivers and lakes (e.g. Anastácio and Marques, 1997; Anastácio et al., 2005). In Africa, P. clarkii spoils valuable fish (tilapia and largemouth bass) caught in gill nets (up to $30 \%$ of the catch) and damages fish nets (Moor, 2002). Attempts to control non-indigenous crayfish species are extremely expensive: the cost for an ongoing attempt to eradicate $P$. leniusculus from Scotland amounts today to GB£250 000 every five months (S. Peay, pers. comm., 2010). Similarly expensive are the projects aimed to reintroduce crayfish species led to local extinction by non-indigenous crayfish: the cost for the reintroduction of Pacifastacus fortis (gone locally extinct due to the competition with the introduced $P$. clarkii) amounted to US $\$ 4.5$ million in California (Gherardi, 2007).

On the other hand, non-indigenous crayfish threaten human health and the health of domesticated or semi-domesticated animals. For example, P. clarkii often lives in areas contaminated by sewage and toxic industrial residues and accumulates high heavy metal concentrations in its tissues (Geiger et al., 2005); it consumes Cyanobacteria that may produce lethal animal and human intoxications (Carmichael, 1988); it may be the agent of transmission of the bacterium Francisella tularensis (McCoy and Chapin) Doroféev, the causative agent of human tularemia (possibly responsible of an outbreak of tularemia in Spain in 1997, affecting about 600 patients; Anda et al., 2001); and it is an intermediate host of helminth parasites of vertebrates (Gherardi, 2007).

\section{> MANAGEMENT REGULATIONS}

Wise management criteria should be applied to avoid the loss of indigenous stocks. There are records of early regulation of harvesting crayfish. Maximilian I (1459-1519), Holy Roman Emperor, drew up rules for catching crayfish. The minimum size of crayfish was burnt into the oar of the fishing boats. The fine was about a hundred time the normal value.

For catchable species, harvest legislations are today in force in many countries. Most of them pose restrictions of catch based on:

(1) Size limits. It consists in setting minimum size at such a level to ensure that females have spawned at least once before they are harvested (Skurdal and Taugbøl, 1994);

(2) No-take zones. No-take zones (areas from which any harvesting is banned) have become an important tool in the management of marine resources. The theory behind no-take zones is that they protect spawning stocks, increasing recruits to adjacent fishing grounds through emigration thus enhancing fisheries (Roberts and Polunin, 1993);

(3) Leaving ovigerous females. The simplest method of protecting brood stock and so reducing the risk of overexploitation is for harvesters to leave crayfish with eggs; and

(4) Constraining fishing methods. Depending on the fishing method, females may be relatively unsusceptible to harvesting, thus providing some automatic protection to the brood stock.

In Europe and North America, legislation varies between countries and even within countries. For example, the minimum size restriction for $P$. leniusculus is $92 \mathrm{~mm}$ total length in Oregon 
and California, $100 \mathrm{~mm}$ in Sweden, and $120 \mathrm{~mm}$ in France (Skurdal and Taugbøl, 2002). The cornerstone of fish management for years has been the concept of "maximum sustainable yield" (MSY): theoretically, it is the largest yield/catch that can be taken from a species' stock over an indefinite period of time to ensure that populations continue through time while still allowing a sustainable harvest. However, MSY application requires a considerable amount of knowledge about biology, ecology, and demography of each single population, which most often are difficult to obtain.

\section{> AQUACULTURE PRODUCTION}

A sustainable aquaculture is regarded to be the best solution to meet market demand without affecting wild stocks. Crayfish are good aquacultural organisms as some species reproduce readily in captivity (Holdich, 1993). They are also nearly unique amongst crustacean decapods in not having larvae (Holdich, 1993): shrimps and prawns typically have 11-12 larval stages which have different dietary requirements from the juveniles and adults, but what hatches out from the crayfish egg already resembles a crayfish and by the time they leave the mother they can feed on most animal and plant foods. Consequently, it is relatively much easier to culture crayfish than prawns and shrimps. However, fecundity is very much lower. Penaeus japonicus (Bate) may produce between 200 000-1000 000 eggs and Macrohrachium rosenbergii De Man 80000 eggs, whilst for cultivated crayfish it varies between 100-1000 depending on the species (Lee and Wickins, 1992). They are polytrophic and will feed on inexpensive feeds.

An historical precedent of crayfish cultivation goes back to John III (1537-1592), king of Sweden since 1568, who farmed crayfish in the moats of Kalmar Castle in southeast Sweden. Although farming methods have been well developed for P. clarkii (Huner, 2002), the aquaculture production of species that are more exigent (in terms of water conditions and food requirements) and more susceptible to diseases is still insufficient. For example, $A$. astacus is farmed in 13 European countries (Westman et al., 1990) but these practices are developed at a very small scale with generally simple technologies (Skurdal and Taugbøl, 2002). To improve indigenous crayfish production more knowledge is needed in fields such as feeding and nutritional requirements, water quality, diseases, behavior, etc.

As a result, it is still today more profitable to farm species tolerant to environmental extremes, highly fecund and growing quickly, i.e. those species that are more likely to be invasive. In order to counteract the uncontrolled introduction of crayfish species in Europe, according to the recent Council Regulation No. 708/07 "concerning use of alien and locally absent species in aquaculture" (European Parliament, 2007), species, with some exceptions (i.e. the species listed in Annex IV), can be imported for aquaculture purposes only after having been appropriately screened thorough a risk assessment analysis. It is interesting to note that the current Annex IV, the list of species to which the Regulation shall not apply (European Parliament, 2008), does not include any crayfish species.

\section{INDIRECT USES}

"What are Cajun folk made of? Scutes and scales and crawdaddy tails - that's what Cajun folk are made of." (Folk song)

\section{$>$ RECREATIONAL VALUES}

Recreational values include sport crayfishing and, most importantly, their use as live bait by anglers, particularly in North America where crayfish are the primary food of important sport fishes, such as smallmouth and largemouth bass (Guiaşu, 2002). A consequence of this use has been the increased spread of the invasive O. rusticus and of other invasive crayfish species in the North American aquatic ecosystems due to bait-bucket introductions (Lodge 
et al., 2000). A 2008 survey of USA and Canadian fisheries agencies revealed the existence of regulations designed to address those problems but the large majority of them do not prohibit the use of live crayfish bait (DiStefano et al., 2009). For example, in Missouri bait shops sell illegal and invasive non-indigenous crayfish and bait shop proprietors are unable to identify the species they are selling (DiStefano et al., 2009). Some crayfish species are even farmed for their use as bait: in Canada, the calico crayfish Orconectes immunis (Hagen) is stocked in the fall at a rate of about 2000 adults per ha or females with eggs are stocked in the spring at the rate of 700-1200 per ha (Hamr, 2002).

Several species of crayfish, particularly non-indigenous species, are kept as household pets by the many crayfish fans. Keeping crayfish both in aquaria and in garden ponds came into fashion during the past two decades, but it soon became a dangerous pathway for the release of non-indigenous crayfish into natural ecosystems. For example, $O$. immunis has been popular since two decades in the aquarium trade in Germany: the first recorded escape was a single individual in a small canal in the Rhine valley of Baden-Württemberg in 1997. Later, a breeding population was discovered, and this has now spread at least as far downstream as Karlsruhe (45 km downstream) and possibly as far as Speyer (35 km downstream from Karlsruhe) (Holdich et al., 2009). It has since been recorded from other locations in Europe, including the German state of Rhineland-Palatinate and France. Another well-known nonindigenous crayfish that have been released to the wild from aquaria is the marbled crayfish or Marmorkrebs, the parthenogenetic form of Procambarus fallax (Hagen) (Martin et al., 2010a), dubbed as "the perfect invader" by Jones et al. (2009). Marmorkrebs circulated in the European pet trade for several years before the first major scientific publication focused on them (Scholtz et al., 2003). They are highly appealing for hobbyists because their marbling is pretty and are the only known parthenogenetic crayfish, which gives them a high novelty value (Faulkes, 2010). The Marmorkrebs appeared in the Austrian and German aquarium trade in the middle of the 1990s (Lukhaup, 2001). Particularly in France, aquariologists are very fond of this species: they propose exchanges, sell and buy through internet. They even gave to the species the (obviously erroneous) Latin name of "Procambarus marmor" with the "Procambarus marmor blue" and "Procambarus marmor cherry" as options (P. Nöel, pers. comm., 2009). It was first recorded in the wild from the Netherlands in 2004 (Soes and van Eekelen, 2006). In Germany, Procambarus sp. is known from at least three sites (Marten et al., 2004; Schulz et al., 2009; Martin et al., 2010b), including a gravel pit near Karlsruhe and a waste treatment pond near Braunschweig (Schulz et al., 2009). Chucholl and Pfeiffer (2010) have recently discovered an established population in a lake in Southwestern Germany. A specimen of Marmorkrebs was found in a population of $P$. clarkii in Tuscany, Italy (Nonnis-Marzano et al., 2009). However, the only country where it has become widely established in the wild is Madagascar, where it is even sold in the markets (Jones et al., 2009; Kawai et al., 2009). Given the poor track record of the pet trade in containing aquatics to their tanks, policy and plans should be enacted in advance to prevent releases into the wild, and mitigate any that may occur - an event that, unfortunately, seems inevitable. The apparent increase in the proportion of Marmorkrebs and other non-indigenous crayfish reported as being bought through pet stores suggests that major commercial retailers should be provided with the best possible information about the ecological risks posed by them (Faulkes, 2010).

\section{> CULTURAL, SOCIAL AND ETHICAL VALUES}

The cultural importance of crayfish in the history of many countries is proven by their appearance in emblems, coats of arms, toponymies and family names. For example, P. clarkii, named Saktce-ho'ma, is the emblem of the Houma Tribe, native to Louisiana (USA); A. pallipes appears in the coat of arms of Cento (Ferrara, Italy) (Figure 4); the Italian municipality of Valdastico

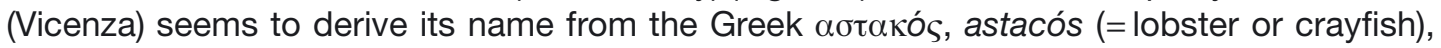
while the villages of Gambellara (Vicenza), Gambara (Brescia), Gambarare (Venice), Gambaro (Piacenza) and Gamberana (Mantova) from the Latin "gambarus" (=crayfish); the Italian family names of Gamberi, Gambari, Gambarini, Gamberini and Gamberucci (a representative of this 


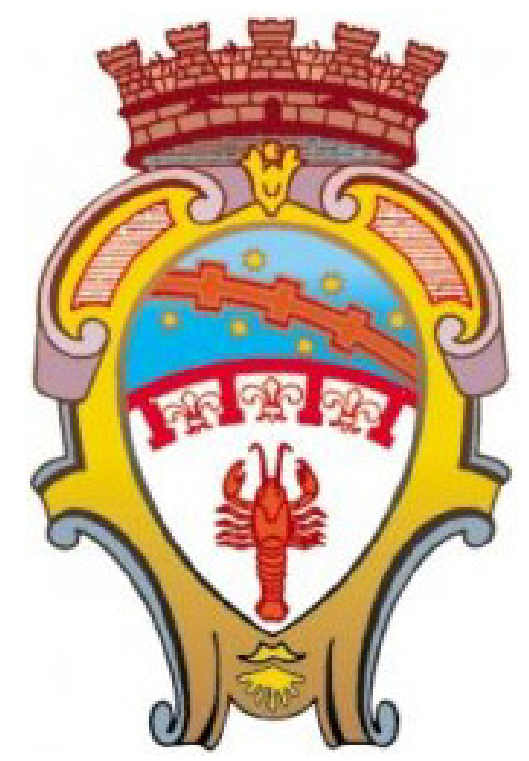

\title{
Figure 4
}

The coat of arms of Cento (in Latin Centum), a municipality in the province of Ferrara, Italy. In the XIIIth century, crayfishing was the main resource of the villagers. Since 1209, a crayfish has appeared in the coat of arms of Cento (also called in Latin Gamberarium) to indicate the permit of crayfishing obtained by the archbishop of Bologna, the owner of the lands and waters in the area. Villagers should reciprocate by offering 100 crayfish per year to the archbishop.

\begin{abstract}
Figure 4
Le blason de Cento, une commune de la province de Ferrara, Italie. Au XIII ${ }^{e}$ siècle, la pêche des écrevisses était la ressource principale des villageois. En 1209, une écrevisse apparaît sur le blason de Cento (appelé également en latin Gamberarium) pour rappeler l'autorisation accordée par l'archevêque de Bologne, le propriétaire des terres et des eaux de cette région. Les villageois offraient en retour 100 écrevisses par an à l'archevêque.
\end{abstract}

family is the Florentine painter Cosimo Gamberucci or Gambaruccio, 1562-1621) seem to have the same derivation (alternatively, they may come from the Langobard name Gàmbara or from gamba, meaning leg).

Since the Middle Ages, crayfish had appeared as the astrological symbol of Cancer, one of the 12 constellations of the Zodiac, often replacing crabs. This shift from crabs to crayfish is exemplified by the pictorial representations of the myth of the second labor of Heracles to slay the multi-headed monster, Lernaean Hydra: seeing that Heracles was winning the struggle, Hera sent Karkinos (Kapkivos, meaning crab or crayfish) to distract him but Heracles crushed it under his foot. Hera, grateful for the effort of Karkinos, turned it into the constellation of Cancer. In early representations, Karkinos was a crab, but in the XVIth century it turned out to be a crayfish (Figure 5). According to Swahn (2004), neither Romans nor Greeks rated crayfish as high as to place them among the stars, but when, in the Middle Ages, crayfish started to be estimated as food, they often replaced crabs in the sky. The possibly oldest representations of crayfish as Cancer are in the rose window on the western front of the Notre-Dame de Paris cathedral (built between the late XIIIth and the early XIVth century) (Swahn, 2004) and in the astrological cycle frescoed by Giotto (1266 ca.-1337) in Palazzo della Ragione in Padoa.

Crayfish are also the subjects of popular traditions. For example, the start of the crayfishing season in Sweden (8th of August), as represented in the 1897 painting by Carl Larrson (1853-1919), was a major event. Many of the New Orleans Mardi Gras traditions and customs refer to $P$. clarkii. Kräftskiva in Sweden and crawfish parties in Louisiana are also important to form and strengthen social cohesion.

Crayfish have been sources of inspiration for arts. Among other examples, the several XIIIth-XVth century frescoes representing the Last Supper kept in churches of the area 


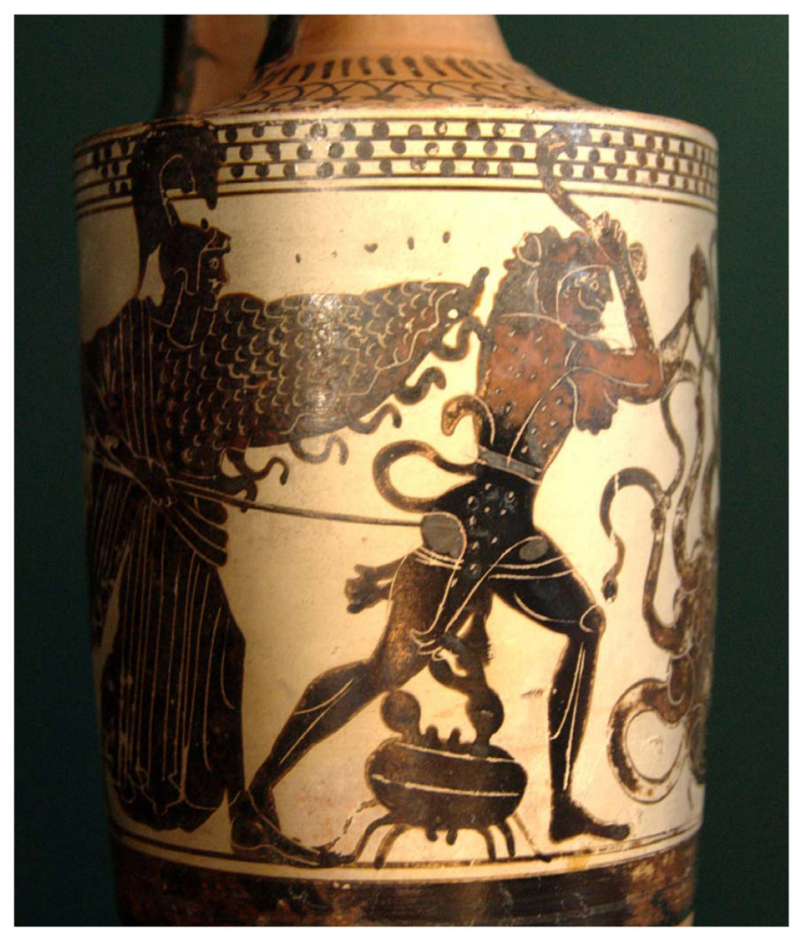

(a)

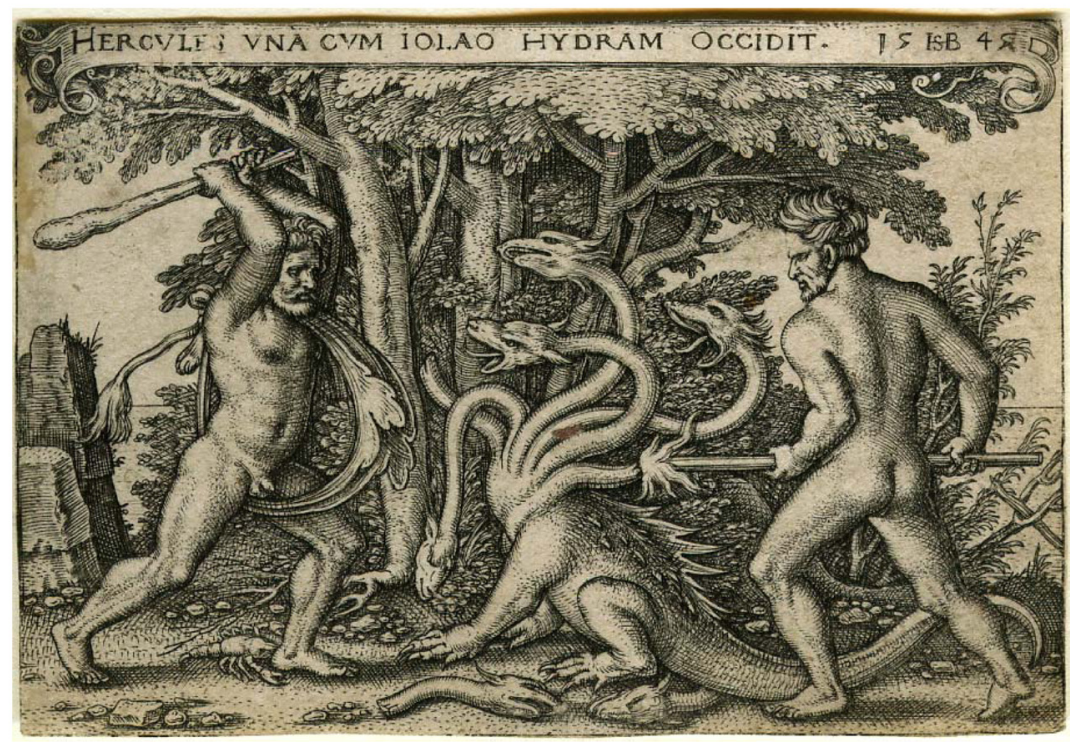

(b)

\section{Figure 5}

The second labor of Heracles as represented in (A) a white-ground Ancient Greek Attic lekythos (=a vase used to store oil) (ca. 500-475 BC; Louvre Museum, Paris) and (B) an engraving by Hans Sebald Beham (1500-1550) from The Labors of Hercules (1542-1548; private collection).

\section{Figure 5}

Le second travail d'Héraclès représenté en (A) sur un lekythos (vase utilisé pour garder l'huile) à fond blanc de l'ancien grec attique (ca. 500-475 av. J.-C.; Musée du Louvre, Paris) et (B) gravure par Hans Sebald Beham (1500-1550) des Travaux d'Héraclès (1542-1548; collection privée). 

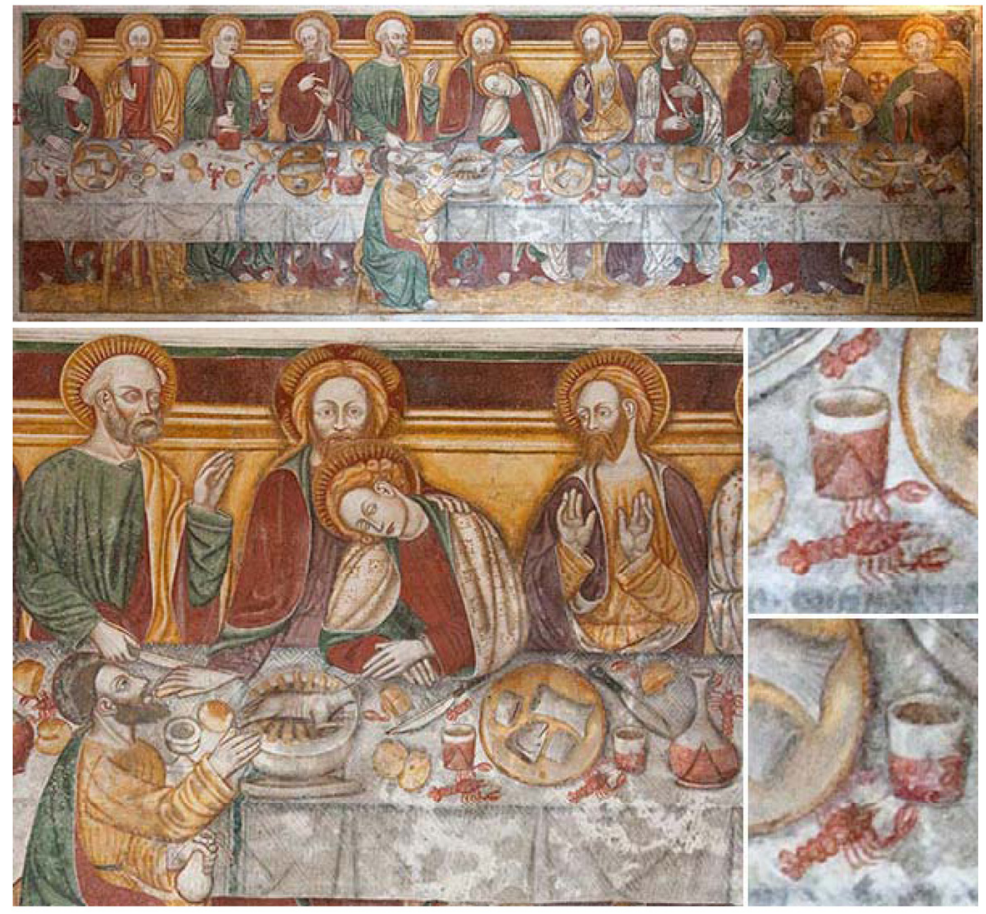

\section{Figure 6}

The Last Supper in the Church of San Giorgio in San Polo di Piave (Treviso) frescoed by Giovanni di Francia in 1466.

\section{Figure 6 \\ Le dernier souper dans l'église de San Giorgio in San Polo di Piave (Trévise), fresque de Giovanni di Francia in 1466.}

comprised between Friuli, Novara Province, Trentino and the Ticino Canton of Switzerland merit to be mentioned (Figure 6). The meaning of crayfish on Jesus' table is debated by art historians, also because crayfish are defined as unclean animals in the Book of Leviticus 11 (see above). Crayfish may represent a typical dish of Lent in that area but they may also symbolize the approaching death; resurrection, heresy and the predestination of Judas' betrayal. Crayfish appear in popular sayings and legends. An example is the Russian коли рак на гори свисне (koly rak na gori svisne), meaning when the crayfish on the hill whistles [When pigs fly, Quand les poules auront des dents, Quando voleranno gli asini] and На безрыбье и ракрыба, meaning on a fishing lull, even a crayfish is fish [Something is better than nothing]. A popular legend regards the mode of catching crayfish by Scandinavian foxes described by Olaus Magnus, the last Catholic Archbishop of Uppsala, in 1555 in "The History of the Northern Peoples", as reported by Swahn (2004): "to catch crayfish, the fox walks to and fro along the shore with his tail dipped in the waters. Lured by this rare sight, the crayfish flock round the tail and thus having entangled themselves in the hairs, it soon pulls them up".

Crayfish feeding habitats and social behavior were described by Huxley (1880) who noted: "few things in the way of food are amiss to the crayfish; living or dead, fresh or carrion, animal or vegetable, it is all one. [...] Crayfishes [...] are guilty of cannibalism in its worst form; and a French observer pathetically remarks, that, under certain circumstances, the males 'méconnaissent les plus saints devoirs'; and, not content with mutilating or killing their spouses, after the fashion of animals of higher moral pretensions, they descend to the lowest depths of utilitarian turpitude, and finish by eating them".

Based on the crayfish's backward swimming, in an emblem of Emblemata Politica in Aula Magna Curiae Noribergensis Depicta by Peter Isselburg (1561-1625), published in 1617, the crayfish with the globe on its back symbolizes the way of the world, or sic orbis iter (thus the 
world goes backwards). More recently, in A passo di gambero. Guerre calde e populismo mediatico (English translation: Turning Back the Clock: Hot Wars and Media Populism; French translation: À reculons, comme une écrevisse), Umberto Eco (2006) enunciated his theory that the machinery of society is not moving in progressive forward gear, but that the engine of change in the new millennium has gone into reverse giving rise to "backward phenomena", e.g. "the resurgence of anti-Darwinian polemic", the redrawing of national and international boundaries, the re-emergence of antisemitism and modern versions of the Crusades. A different interpretation of the crayfish way of moving appears in Günter Wilhelm Grass' (2002) Im Krebsgang (Italian translation: II passo del gambero; English translation: Crabwalk; French translation: En crabe) [note that the erroneous reference to crabs in the English and French translations]: it is defined by Grass as "scuttling backward to move forward", meaning the process of scouring the wreckage of history for therapeutic insights that allow people to proceed forward.

\section{USES IN SCIENCE AND EDUCATION}

"In writing this book about Crayfishes it has not been my intention to compose a zoological monograph on that group of animals. [...] What I have had in view is a much humbler, though perhaps [...] not less useful object. I have desired, in fact, to show how the careful study of one of the commonest and most insignificant of animals, leads us, step by step, from everyday knowledge to the widest generalizations and the most difficult problems of zoology; and, indeed, of biological science in general." (Huxley, 1880)

Since Aristotle (384 BC-322 BC; see e.g. De Incessu Animalium, 350 BC), crayfish have been models for science and technology. Since Aristotle's times, over 11000 citations pertaining to crayfish have been documented until 1985 (Hart and Clark, 1987). Huxley wrote an introductory text to the study of zoology solely based on crayfish, "The Crayfish: An Introduction to the Study of Zoology" (1880). His purpose, he says, "is to exemplify the general truths respecting the development of zoological science which have just been stated by the study of a special case; and, to this end, I have selected an animal, the Common Crayfish, which, taking it altogether, is better fitted for my purpose than any other".

Other famous scientists who used crayfish as model organisms include Freud (1856-1939), Yerkes (1876-1956) and, more recently, Wald (1906-1997). After his doctoral dissertation, the young Freud worked in the laboratory of Ernst Brücke, where he studied crayfish as models in neurobiology (Freud, 1882). Yerkes investigated habit formation in Orconectes virilis (Yerkes and Huggins, 1903). Wald was the 1967 Nobel Laureate in Medicine for discoveries concerning the primary physiological and chemical visual processes in the eye, using the crayfish in his elucidation of the role of vitamin A in vision (Wald, 1967, 1968). In the latest decades, the key role of crayfish as model organisms for science is increasing: since 1990, an average of 141 articles per year with crayfish as the primary subjects of study has been published in peer-reviewed journals (Figure 7).

The importance of crayfish for the development of science and technology is extremely high, as illustrated by the examples that follow. The neurons of the abdominal stretch receptor organs (MROs) of crayfish have been used to explore the mechanisms of photodynamic therapy: this technique elicits death of cells under light exposure via dye-mediated oxygen stress and is successfully used for the treatment of cancer (Fedorenko and Uzdensky, 2008). Investigations on the immune response of crayfish to experimentally induced neoplasias may contribute to the understanding of how an organism can successfully prevent or control spontaneous and environmentally induced cell proliferation (Vogt, 2008). The optical principles of the compound eye of crayfish have evoked ideas for the construction of a new type of X-ray telescope and a collimator to produce a parallel beam from an X-ray source, which might be useful in forming ultrafine microcircuits on a chip (Land, 2000). The mechanoreceptors on $P$. clarkii's tailfan have been the first biological system in which scientists discovered the phenomenon of stochastic resonance (Douglass et al., 1993), a phenomenon that has found useful applications in physical, technological and biomedical contexts. 


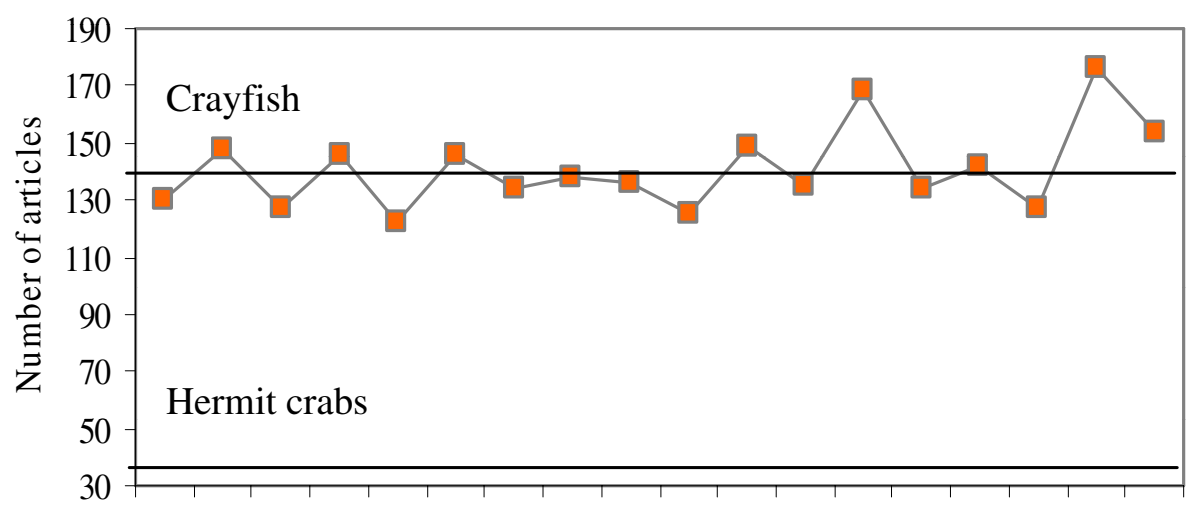

$\begin{array}{llllllllllllllllll}90 & 91 & 92 & 93 & 94 & 95 & 96 & 97 & 98 & 99 & 00 & 01 & 02 & 03 & 04 & 05 & 06 & 07\end{array}$

Year

\section{Figure 7}

Number of papers regarding crayfish published between 1990 and 2008 in peer-reviewed journals, compared to the average number of papers regarding another highly studied crustacean decapod taxon, hermit crabs (after Web of Science).

\section{Figure 7}

Nombre d'articles concernant les écrevisses publiés entre 1990 et 2008 dans des journaux à comité de lecture comparé au nombre moyen d'articles concernant un autre taxon de crustacé décapode bien étudié, les bernards l'hermite (d'après le Web of Science).

Finally, crayfish species, and particularly $O$. rusticus and $P$. clarkii, are often used in classrooms as they are easy to keep in captivity in warm laboratories. There is no doubt that this use is crucial for conservation purposes since the contact with crayfish has the potential to stimulate curiosity and respect for them in young generations. On the other side, the use of potentially invasive crayfish in biological classes raises the risk of their release alive into the wild. Euthanasia is a difficult topic in a classroom setting in which students may have become attached to laboratory organisms, but it is important to teach the students that animals released from captivity have already caused great harm to indigenous populations and ecosystems. A collaboration among scientists, science curricula developers and biological supply companies could better address this issue in the long term.

\section{INDIRECT USE AS SURROGATE SPECIES}

"A much better keyword instead of "bioindicator" would be "flagship species", especially because of their "cultural heritage" value. In this sense crayfish may act as a "surrogate species" of particular use in biological conservation." (Füreder and Reynolds, 2003)

Because of their ecological importance, crayfish have been often used as "surrogate" species (sensu Caro and O'Doherty, 1999). They may:

(1) indicate the extent of different anthropogenic impacts ("health indicator species");

(2) track population changes of other species ("population indicator species");

(3) locate areas of high biodiversity ("biodiversity indicator species");

(4) act as "umbrellas" for the requirements of sympatric species ("umbrella species"); and

(5) attract the attention of the public ("flagship species") (Füreder et al., 2003).

For example, due to their homotopic (solely aquatic) and benthic life form, crayfish species are necessarily dependent on specific features of the aquatic ecosystem. As such, the presence of some of these species and their health have been regarded as good indicators of ecosystem integrity, whereas the shrinking in their abundance and distribution may alert about anthropogenically induced environmental changes. Indeed, several studies have shown that 
habitat heterogeneity, water quality and lack of pollutants enhance or ensure the survival of some indigenous species (e.g. Füreder et al., 2003; Trouilhé et al., 2003). Often, the decline or the extinction of indigenous crayfish has been observed in areas with extensive land use, crayfish being highly sensitive to a great variety of fertilizers, insecticides and pesticides (Eversole et al., 1995). Other forms of anthropogenic impacts, such as deforestation, reduction of riparian vegetation and river regulation, may also have clear negative effects on crayfish habitat and food availability. However, there are also examples showing that crayfish populations occur in several kinds of environmental conditions, including degraded waterbodies (e.g., Demers and Reynolds, 2002; Füreder et al., 2003). An example is A. pallipes, an endangered species (Füreder et al., 2010) typically believed to be demanding in terms of water and habitat quality (Broquet et al., 2002), and considered sensitive to different forms of environmental degradation and effective in tracking temporal and local changes. Interestingly, however, in parts of eastern France (Alsace) and in Switzerland, A. pallipes is named Dohlenkrebs, meaning "sewer crayfish" (Laurent, 1988), which might raise doubts about its role of indicator of high water quality. This role has recently been questioned also from a scientific point of view (Füreder and Reynolds, 2003). Demers and Reynolds (2002), for example, has shown that, in Ireland, $A$. pallipes can be found in moderately polluted waters. More recently, Trouilhé et al. (2007) found that in France this species is able to tolerate wide ranges in the value of some physico-chemical water parameters: the site that harbored the largest A. pallipes population of the study $\left(17.5\right.$ crayfish $\left.\cdot \mathrm{m}^{-2}\right)$ had dissolved oxygen concentrations as low as $4.93 \mathrm{mg} \cdot \mathrm{L}^{-1}$, while water temperature rose above $20{ }^{\circ} \mathrm{C}$ for several consecutive days during summer and nitrate concentrations were always found to be above $30 \mathrm{mg} \cdot \mathrm{L}^{-1}$.

Often, crayfish species have been regarded as "sentinels" for assessing chemical and biological contamination. For example, crayfish can be used to monitor the aquatic environments for heavy metal pollution because they are bottom dwellers and readily accumulate metals in their tissues. Such accumulation is dose- and time-dependent, and therefore may be reflective of the environmental levels of those metals (e.g. Allert et al., 2009). Crayfish species meet several criteria that make them suitable as bioindicators of heavy metals in the environment. For example, as reported by Kouba et al. (2010), A. astacus is easily identified, has a relatively long life cycle, and its populations can be abundant and widespread; the species has a small home range and shows a relatively sedentary lifestyle, specimens being therefore representative of the locations in which they are caught. They are easily captured and the total body length of adults $(70-95 \mathrm{~mm})$ provides sufficient tissue for individual analyses. Furthermore, for most species the concentration of metals in the environment is not sufficient to be a direct cause of death and crayfish are on the contrary resistant to environmental metal contamination (Chambers, 1995). A number of studies have addressed contaminants' accumulation into tissues of a variety of species under different concentrations and times of exposure in both the field (e.g. Khan et al., 1995: Pb, Cd, Cu, Zn, Co, Ni and Hg in O. virilis; Schilderman et al., 1999: PCBs, PAHs, Zn, Cu, Pb and Cd in O. limosus; Gherardi et al., 2002: Cd, Cu, Fe, Mg, $\mathrm{Mn}, \mathrm{Ni}, \mathrm{Pb}$ and $\mathrm{Zn}$ in A. pallipes and P. clarkii; Alcorlo et al., 2006: $\mathrm{Cd}, \mathrm{Cu}, \mathrm{Zn}, \mathrm{Pb}$ and $\mathrm{As}$ in P. clarkii) and the laboratory (Alikhan et al., 1990: Cu, Cd, Fe, Mn, Ni and $\mathrm{Zn}$ in C. bartoni; Meyer et al., 1991: Pb and Cd in A. astacus; Allinson et al., 2000: Cu in C. destructor).

Crayfish, and particularly invasive populations of some crayfish species, may be used to assess the ecological status of waterbodies under the EU Water Framework Directive (WFD, 2000/60/EC; European Community, 2000). Although invasive alien species (IAS) are not mentioned specifically in the WFD, they obviously represent an important pressure since they can modify the native biological structure and ecological functioning of aquatic systems. This recognition has initiated a debate on the role of IAS in ecological status classifications (IMPRESS, 2003; REFCOND, 2003). Some EU member states have acknowledged this to be the case and the European Commission agreed to include alien species as an item for discussion to the 2010-2012 mandate of the WFD Working Group on Ecological Status (ECOSTAT).

In 2004, the UK government administrations in England, Wales, Scotland and Northern Ireland agreed that alien species should be included as part of the assessment of pressures and impacts. The procedure proposed by the UK Technical Advisory Group on the WFD (UKTAG) 
for taking account of alien species in classification decisions is schematized as follows. Any waterbody containing an established population of a species of high impact for UK waters, including the crayfish $O$. limosus, $P$. leniusculus, Procambarus sp. and $P$. clarkii, cannot be classified as being at high status, even if ecological impacts have not yet been recorded, but its status should be downgraded. Such downgrading is based on past evidence showing that, to the appearance of one of these species, severe ecosystem impacts will invariably follow. Finally, because of the relatively large size and the splendor of morphological variation, characterized by bizarre shapes, many colors and patterns of various sorts, crayfish attract the attention of the public at large. As such, they represent good candidates to be used as "flagship species", i.e. species chosen to represent an environmental cause, such as ecosystems in need of conservation. On the one hand, by giving publicity to them, public support will hopefully leverage conservation of entire ecosystems and of all species contained therein. On the other hand, the role of flagship species in a negative sense can be played by some invasive crayfish, such as $P$. clarkii: their ecological and negative impacts may raise awareness about the general problem of biological invasions. Much work, however, has to be done in this direction. As recently shown in southern Spain (García-Llorente et al., 2008), most stakeholders have a limited knowledge of the invasive nature of $P$. clarkii and show different perceptions of its impacts and different attitudes toward its management.

\section{OTHER USES OF CRAYFISH}

"The role played by crayfish in the history of medicine is not uninteresting, because it has two diametrically opposite aims, both to explain causes of disease and to cure illness." (Swahn, 2004)

From classical antiquity until a century ago, crayfish have been used in both scientific and popular pharmacology. In most cases they have been recommended as a remedy against cancer. It is interesting to note that Hippocrates of Cos (ca. 460 BC-ca. 370 BC) used the Greek word Kapkivos, meaning both crab and crayfish, to refer to malignant tumors. According to Moss (1989), it was the Byzantine-Greek physician Paul of Aegina (VIlth century AD) who explained the use of this name for the disease from the appearance of the cut surface of a solid malignant tumor, with "the veins stretched on all sides as the crayfish has its feet". This association between the disease and crayfish/crab is possibly at the origin of a common and widely spread fallacy concerning crayfish in the folk medicine of the XVIIIth century, i.e. that cancer is spread by flies from sick crayfish to humans (Swahn, 2004).

Crayfish were regarded as good in the treatment of many diseases other than cancer. Some of these uses, at least in western Europe, have been told by Swahn (2004). In 1522, Peder Månsson, bishop in the diocese of Västerås, west of Stockholm, recommended the use of crayfish dissolved in alcohol as a remedy against cholera. Medical books from the XVIth century report that the juice released by female crayfish crushed in a mortar makes hard labor pains easier and accelerate the ejection of the afterbirth. The same liquid was believed to cure dry eczema, sunburn, pain of hearth, epilepsy, venereal diseases, tuberculosis, etc. It was also regarded as an analgesic in general and as a sudorific, being also good against heartburn. The ashes of burnt crayfish hearts were used against epilepsy (Kanner, 1930). Five hundred years ago doctors ordered gastroliths, "crayfish stones", as a remedy against plague; one hundred years ago crayfish stones could be bought in pharmacies. Pulverized crayfish stones could be swallowed to cure heartburn, stones in the bladder (even recommended by Martin Luther), vomiting of blood and epilepsy (Münsterer, 1955). Gastroliths also served a purpose within popular dentistry: they could be pasted in tooth cavities by means of wax and resin from cherry trees. Crayfish stones were used, along with pearls and coral, to produce the Martial salt prescribed to the 16-year old King Luis XIV (1638-1715), the Sun King, as a remedy of gonorrhea he had contracted during his first love adventures with Madame de Beauvais (O'Malley, 1969).

Other, more recent, uses of crayfish regarding the control of nuisance macrophytes (Guiaşu, 2002) and of invasive populations of zebra mussel and Corbicula spp. (Covich et al., 1981; 
Hazlett, 1994) derive from their voracious feeding behavior. Finally, in Africa several projects of introduction of crayfish, specifically of $P$. clarkii, were motivated by the ability of this crayfish species to drastically reduce the population size of pulmonate snails Biomphalaria and Bulinus, known to host Schistosoma spp., the agents of human schistosomiasis. Schistosomiasis is one of the most widespread diseases in Africa: in Kenya alone, it is known to affect 3.5 million individuals with 12 million more at risk of infection. As suggested by Mkoji et al. (1999), due to the quick spread of this crayfish in African waterbodies, the epidemiology of schistosomiasis is expected to be significantly altered with time, although the possibility remains that African snails will soon evolve measures to avoid crayfish predation before their extinction or that the parasite will change its host (Gherardi, 2007).

\section{CONCLUSIONS}

"The option value may have only a sentimental basis in some instances. [. . .] An option demand may exist not only among persons currently and prospectively active in the market for the object of the demand, but among others who place a value on the mere existence of biological and/or geomorphological variety and its widespread distribution." (Krutilla, 1967).

Although far from being exhaustive, this review has shown that crayfish are an important group of organisms from the human point of view: they exert a strong impact on human history and incorporate a remarkable "cultural heritage" value (Füreder and Reynolds, 2003). Their effect on ecosystem services (MEA, 2005) is wide and deep. They act on (1) supporting services by influencing the major ecosystem resources, (2) provisioning services by providing food to various human societies, (3) regulating services by contributing to the maintenance of ecosystem processes and (4) cultural services by offering non-material benefits.

Crayfish offer options for future novel uses of them. Indeed, some of their properties that are not of value to us at present may become valuable at some time later: the history of science teaches us that, as our knowledge improves and as circumstances change, we come to discover new ways in which biological entities, such as crayfish, can be used. Crayfish's option values further corroborate our belief that, since we do not know in advance all their potential importance, we should be cautious and try to conserve as rich and representative a sample of this taxon as possible. Finally, there is another, less obvious reason that calls for a sustainable use of crayfish, a reason which is independent of the goods and services they either directly or indirectly provide to humans. It is their intrinsic value that comes from simply knowing that crayfish exist (i.e. existence value) or that they may be left behind for the next generations (i.e. bequest value). Hopefully, existence and bequest values will provide per se the rationale for protecting this taxon without the need of conjuring up images of cooked crayfish (Gherardi et al., 2010).

\section{ACKNOWLEDGEMENTS}

My warmest thanks are directed to Prof. Catherine Souty-Grosset for her kind invitation to the successful conference "European Crayfish: food, flagships \& ecosystem services" held in Poitiers in October 2010.

\section{REFERENCES}

Ackefors H., 1999. The positive effects of established crayfish. In: Gherardi F. and Holdich D.M. (eds.), Crayfish in Europe as Alien Species. How to Make the Best of a Bad Situation?, A.A. Balkema Rotterdam, 49-61.

Alcorlo P., Otero M., Crehuet M., Baltanás A. and Montes C., 2006. The use of the red swamp crayfish (Procambarus clarkii, Girard) as indicator of the bioavailability of heavy metals in environmental monitoring in the River Guadiamar (SW, Spain). Sci. Total Environ., 366, 380-390. 
Alikhan M.A., Bagatto G. and Zia S., 1990. The crayfish as a "biological indicator" of aquatic contamination by heavy metals. Water Res., 24, 1069-1076.

Allert A.L., Fairchild J.F., DiStefano R.J., Schmitt C.J., Brumbaugh W.G. and Besser J.M., 2009. Ecological effects of lead mining on Ozark streams: in-situ toxicity to woodland crayfish (Orconectes hylas). Ecotoxicol. Environ. Safety, 72, 1207-1219.

Allinson G., Laurenson L.J.B., Pistone G., Stagnitti F. and Jones P.L., 2000. Effects of dietary copper on the Australian freshwater crayfish Cherax destructor. Ecotoxicol. Environ. Safety, 46, 117-123.

Anastácio P.M. and Marques J.C., 1997. Crayfish, Procambarus clarkii, effects on initial stages of rice growth in the lower Mondego River valley (Portugal). Freshw. Crayfish, 11, 608-617.

Anastácio P.M., Parente V.S. and Correia A.M., 2005. Crayfish effects on seeds and seedlings: identification and quantification of damage. Freshw. Biol., 50, 697-704.

Anda P., Segura del Pozo J., Díaz García J.M., Escudero R., García Peña F.J., López Velasco M.C., Sellek R.E., Jiménez Chillarón M.R., Sánchez Serrano L.P. and Martínez Navarro J.F., 2001. Waterborne outbreak of tularemia associated with crayfish fishing. Emerg. Infect. Dis., 7, 575-582.

Barbaresi S. and Gherardi F., 2000. The invasion of the alien crayfish Procambarus clarkii in Europe, with particular reference to Italy. Biol. Invasions, 2, 259-264.

Broquet T., Thibault M. and Neveu A., 2002. Distribution and habitat requirements of the white clawedcrayfish, Austropotamobius pallipes, in a stream from the pays de Loire region, France: an experimental and descriptive study. Bull. Fr. Pêche Piscic., 367, 717-728.

Buckup L., Dutra B.K., Ribarcki F.P., Fernandes F.A., Noro C.K., Oliveira G.T. and Vinagre A.S., 2008. Seasonal variations in the biochemical composition of the crayfish Parastacus defossus (Crustacea, Decapoda) in its natural environment. Comp. Biochem. Physiol., 149A, 59-67.

Carmichael W.W., 1988. Toxins of freshwater algae. In: Tu A.T. (ed.), Handbook of Natural Toxins, Vol. 3 , Marine toxins and venoms, Marcel Dekker, New York, 121-147.

Caro T.M. and O'Doherty G., 1999. On the use of surrogate species in conservation biology. Biol. Conserv., 13, 805-814.

Chambers M.G., 1995. The effect of acute cadmium toxicity on marron, Cherax tenuimanus (Smith, 1912) (Family Parastacidae). Freshwater Crayfish, 10, 209-220.

Chucholl C. and Pfeiffer M., 2010. First evidence for an established Marmorkrebs (Decapoda, Astacida, Cambaridae) population in Southwestern Germany, in syntopic occurrence with Orconectes limosus (Rafinesque, 1817). Aquat. Invasions, 5, 405-412.

Covich A.P., Dye L.L. and Mattice J.S., 1981. Crayfish predation on Corbicula under laboratory conditions. Am. Midl. Nat., 105, 181-188.

Crandall K.A. and Buhay J.E., 2008. Global diversity of crayfish (Astacidae, Cambaridae, and Parastacidae - Decapoda) in freshwater. Hydrobiologia, 595, 295-301.

Demers A. and Reynolds J.D., 2002. A survey of the white-clawed crayfish, Austropotamobius pallipes (Lereboullet), and of water quality in two catchments of eastern Ireland. Bull. Fr. Pêche Piscic., 367, 729-740.

DiStefano R.J., Litvan M.E. and Horner P.T., 2009. The bait industry as a potential vector for alien crayfish introductions: problem recognition by fisheries agencies and a Missouri evaluation. Fisheries, 34, 586-597.

Douglass J.K., Wilkens L.A., Pantazelou E. and Moss F., 1993. Noise enhancement of information transfer in crayfish mechanoreceptors by stochastic resonance. Nature, 365, 337-340.

Eco U., 2006. A passo di gambero. Guerre calde e populismo mediatico, Bompiani, Milano.

European Community, 2000. Directive 2000/60/EC of the European Parliament and of the Council of 23 October 2000 establishing a framework for Community action in the field of water policy. OJEC, L327, 1-72.

European Parliament, 2007. Council regulation (EC) No. 708/2007 of 11 June 2007 concerning use of alien and locally absent species in aquaculture. OJL, 168, 1-9.

European Parliament, 2008. Commission regulation (EC) No. 535/2008 of 13 June 2008 laying down detailed rules for the implementation of Council Regulation (EC) No 708/2007 concerning use of alien and locally absent species in aquaculture. OJL, 168, 1-17.

Eversole A.G., Whetstone J.M. and Seller B.C., 1995. Handbook of Relative Acute Toxicity Values for Crayfish, Clemson University, USA.

Faulkes Z., 2010. The spread of the parthenogenetic marbled crayfish, Marmorkrebs (Procambarus sp.), in the North American pet trade. Aquat. Invas., 5, 447-450.

Fedorenko G.M. and Uzdensky A.B., 2008. Dynamics of ultrastructural changes in the isolated crayfish mechanoreceptor neuron under photodynamic impact. J. Neuro. Res., 86, 1409-1416. 
Freud S., 1882. Über den Bau der Nervenfasern und Nervenzellen beim Flusskrebs. Sitz. K. Akad. Wiss. Wien, 85, 9-46.

Füreder L. and Reynolds J.R., 2003. Is Austropotamobius pallipes a good bioindicator? Bull. Fr. Pêche Piscic., 370-371, 157-163.

Füreder L., Oberkofler B., Hanel R., Leiter J. and Thaler B., 2003. The freshwater crayfish Austropotamobius pallipes in South Tyrol: Heritage species and bioindicator. Bull. Fr. Pêche Piscic., 370-371, 81-95.

Füreder L., Gherardi F., Holdich D., Reynolds J., Sibley P. and Souty-Grosset C., 2010. Austropotamobius pallipes. In: IUCN 2010. IUCN Red List of Threatened Species, Version 2010.4, www.iucnredlist.org.

García-Llorente M., Martín-López B., González J.A., Alcorlo P. and Montes C., 2008. Social perceptions of the impacts and benefits of invasive alien species: implications for management. Biol. Conserv., 141, 2969-2983.

Geiger W., Alcorlo P., Baltanás A. and Montes C., 2005. Impact of an introduced Crustacean on the trophic webs of Mediterranean wetlands. Biol. Invasions., 7, 49-73.

Gherardi F., 2006. Crayfish invading Europe: the case study of Procambarus clarkii. Mar. Freshw. Behav. Physiol., 39, 175-191.

Gherardi F., 2007. Understanding the impact of invasive crayfish. In: Gherardi F. (ed.), Biological Invaders in Inland Waters: Profiles, Distribution, and Threats, Springer, Dordrecht, The Netherlands, 507-542.

Gherardi F., Barbaresi S., Vaselli O. and Bencini A., 2002. A comparison of trace metal accumulation in indigenous and alien freshwater macro-decapods. Mar. Freshw. Behav. Physiol., 35, 179-188.

Gherardi F., Souty-Grosset C., Vogt G., Diéguez-Uribeondo J. and Crandall K.A., 2010. Infraorder Astacidea Latreille, 1802 P.P.: The Freshwater Crayfish, Chapter 67. In: Schram F.R. and von Vaupel Klein J.C. (eds.), Treatise on Zoology - Anatomy, Taxonomy, Biology - The Crustacea, Decapoda, Vol. 9, Part A - Eucarida: Euphausiacea, Amphionidacea, and Decapoda (partim), Brill, Leiden, The Netherlands, 269-423.

Gherardi F., Britton J.R., Mavuti K.M., Pacini N., Grey J., Tricarico E. and Harper D.M., to appear. A review of allodiversity in Lake Naivasha, Kenya: developing conservation actions to protect East African lakes from the impacts of alien species. Biol. Conserv.

Gouin N., Grandjean F., Pain S., Souty-Grosset C. and Reynold J., 2003. Origin and colonization history of the white-clawed crayfish, Austropotamobius pallipes, in Ireland. Heredity, 91, 70-77.

Grass G., 2002. Im Krebsgang, Steidl-Verlag, Göttingen, Germany.

Guiaşu R.C., 2002. Cambarus. In: Holdich D.M. (ed.), Biology of Freshwater Crayfish, Blackwell Science, Oxford, 609-634.

Gydemo R., 1989. Studies on reproduction and growth in the noble crayfish Astacus astacus L., Ph.D. thesis, University of Stockholm, Sweden.

Hamr P., 2002. Orconectes. In: Holdich D.M. (ed.), Biology of Freshwater Crayfish, Blackwell Science, Oxford, 585-608.

Harper D.M., Mavuti K.M., Muchiri S.M., 1990. Ecology and management of Lake Naivasha, Kenya, in relation to climatic change, alien species introductions, and agricultural development. Environ. Conserv., 17, 328-336.

Hart C.W. and Clark J., 1987. An interdisciplinary bibliography of freshwater crayfishes (Astacoidea and Parastacoidea) from Aristotle through 1985. Smithson. Contrib. Zool., 455, 1-437.

Hazlett B.A., 1994. Crayfish feeding responses to zebra mussels depend on microorganisms and learning. J. Chem. Ecol., 20, 2623-2630.

Holdich D.M., 1993. A review of astaciculture: freshwater crayfish farming. Aquat. Living Resour., 6, 307-317.

Holdich D.M., 1999. The negative effects of established crayfish introductions. In: Gherardi F. and Holdich D.M. (eds.), Crayfish in Europe as Alien Species. How to Make the Best of a Bad situation?, A.A. Balkema, Rotterdam, 31-47.

Holdich D.M. (ed.), 2002. The Biology of Freshwater Crayfish, Blackwell, Oxford.

Holdich D.M., Reynolds J.D., Souty-Grosset C. and Sibley P.J., 2009. A review of the ever increasing threat to European crayfish from non-indigenous crayfish species. Kwol. Managt. Aquatic Ecosyst., 394-395, 11.

Huner J.V., 2002. Procambarus. In: Holdich D.M. (ed.), Biology of Freshwater Crayfish, Blackwell Science, Oxford, 541-584. 
Huxley T.H., 1880. The Crayfish: An Introduction to the Study of Zoology, C. Kegan Paul \& Co., London. IMPRESS, 2003. Common implementation strategy for the Water Framework Directive (2000/60/EC), guidance document 3 , analysis of pressures and impacts. Office for Official Publications of the European Communities, Luxembourg, http://circa.europa.eu/Public/irc/env/wfd/library.

Jones J.P.G., 2004. The sustainability of crayfish harvesting in Ranomafana National Park, Madagascar, Ph.D. thesis, University of Cambridge, UK.

Jones J.P.G., Andriahajaina F.B., Ranambinintsoa E.H., Hockley N.J. and Ravoahangimalala O.R., 2006. The economic importance of freshwater crayfish harvesting in Madagascar and the potential of community-based conservation to improve management. Oryx, 40, 168-175.

Jones J.P.G., Rasamy J.R., Harvey A., Toon A., Oidtmann B., Randrianarison M.H., Raminosoa N. and Ravoahangimalala O.R., 2009. The perfect invader: a parthenogenetic crayfish poses a new threat to Madagascar's freshwater biodiversity. Biol. Invasions., 11, 1475-1482.

Kanner L., 1930. The folklore and cultural history of epilepsy. Med. Life, 37, 167-214.

Kaufman L., 1992. Catastrophic change in species-rich freshwater ecosystems. BioScience, 42, 846-858.

Khan A.T., Forester D.M. and Mileke H.W., 1995. Heavy metal concentrations in two populations of crayfish. Vet. Hum. Toxicol., 37, 426-428.

Kawai T., Scholtz G., Morioka S., Ramanamandimby F., Lukhaup C. and Hanamura Y., 2009. Parthenogenetic alien crayfish (Decapoda: Cambaridae) spreading in Madagascar. J. Crust. Biol., 29, 562-567.

Köksal G., 1988. Astacus leptodaclus in Europe. In: Holdich D.M. and Lowery R.S. (eds.), Freshwater Crayfish: Biology, Management and Exploitation, Chapman and Hall, London, 365-400.

Kouba A., Buřič M. and Kozák P., 2010. Bioaccumulation and effects of heavy metals in crayfish: a review. Water Air Soil Pollut., 211, 5-16.

Krutilla J.V., 1967. Conservation reconsidered. Am. Econ. Rev., 57, 777-786.

Kusabs I.A. and Quinn J.M., 2009. Use of a traditional Maori harvesting method, the tau koura, for monitoring koura (freshwater crayfish, Paranephrops planifrons) in Lake Rotoiti, North Island, New Zealand. N. Z. J. Mar. Freshw. Res., 43, 713-722.

Land M.F., 2000. Eyes with mirror optics. J. Opt. Pure Appl. Opt., 2, 44-50.

Laurent P.J., 1988. Austropotamobius pallipes and Austropotamobius torrentium with observations in their interactions with other species in Europe. In: Holdich D.M. and Lowery R.S. (eds.), Freshwater Crayfish: Biology, Management and Exploitation, Chapman and Hall, London, 341-364.

Lee D.O'C. and Wickins J.F., 1992. Crustacean Farming, Blackwell, Oxford.

Lodge D.M., Taylor C.A., Holdich D.M. and Skurdal J., 2000. Nonindigenous crayfishes threaten North American freshwater biodiversity. Fisheries, 25, 7-20.

Lukhaup C., 2001. Procambarus sp. - Der Marmorkrebs. Aquaristik aktuell, 7-8, 48-51.

Marten M., Werth C. and Marten D., 2004. Der Marmorkrebs Procambarus sp. (Cambaridae, Decapoda) in Deutschland - ein weiteres Neozoon im Rheineinzugsgebiet. Lauterbornia, 50, 17-23.

Martin P., Dorn N.J., Kawai T., van der Heiden C. and Scholtz G., 2010a. The enigmatic Marmorkrebs (marbled crayfish) is the parthenogenetic form of Procambarus fallax (Hagen, 1870). Contrib. Zool., 79, 107-118.

Martin P., Shen H., Füllner G. and Scholtz G., 2010b. The first record of the parthenogenetic Marmorkrebs (Decapoda, Astacida, Cambaridae) in the wild in Saxony (Germany) raises the question of its actual threat to European freshwater ecosystems. Aquat. Invas., 5, 397-403.

Meyer W., Kretschmer M., Hoffmann A. and Harisch G., 1991. Biochemical and histochemical observations on effects of low-level heavy metal load (lead, cadmium) in different organ systems of the freshwater crayfish, Astacus astacus L. (Crustacea: Decapoda). Ecotoxicol. Environ. Saf., 21, $137-156$.

Moor I. de, 2002. Potential impacts of alien freshwater crayfish in South Africa. Afr. J. Aquat. Sci., 27, $125-139$.

Mkoji G.M., Hofkin B.V., Kuris A.M., Stewart-Oaten A., Mungai B.N., Kihara J.H., Mungai F., Yundu J., Mbui J., Rashid J.R., Kariuki C.H., Ouma J.H., Koech D.H. and Loker E.S., 1999. Impact of the crayfish Procambarus clarkii on Schistosoma haematobium transmission in Kenya. Am. J. Trop. Med. Hyg., 61, 751-759.

Moss R.W., 1989. Galen on cancer: how ancient physicians viewed malignant disease. Speeches and Presentations for Professional Audience, http://www.cancerdecisions.com/speeches/galen1989. html. 
Münsterer H.O., 1955. Verschiedenes Krebsaugen. Aufstieg und Niedergang eines Medikaments. Münch. Med. Wochenschrift, 97, 1543-1544.

Nonnis-Marzano F., Scalici M., Chiesa S., Gherardi F., Piccinini A. and Gibertini G., 2009. The first record of the marbled crayfish adds further threats to fresh waters in Italy. Aquat. Invas., 4, 401-404.

O'Malley C.D., 1969. The medical history of Louis XIV: intimations of mortality. In: Rule J.C. (ed.), Louis XIV and the Craft of Kingship, Ohio State University Press, Columbus, 132-154.

REFCOND, 2003. Common implementation strategy for the Water Framework Directive (2000/60/EC), guidance document 10, river and lakes - typology, reference conditions and classification systems. Office for Official Publications of the European Communities, Luxembourg, http://circa.europa.eu/ Public/irc/env/wfd/library.

Roberts C.M. and Polunin N.V.C., 1993. Marine reserves: simple solutions to managing complex fisheries? Ambio, 22, 363-368.

Schilderman P.A.E.L., Moonen E.J.C., Maas L.M., Welle I. and Kleinjans J.C.S., 1999. Use of crayfish in biomonitoring studies of environmental pollution of the River Meuse. Ecotoxicol. Environ. Saf., 44, 241-252.

Scholtz G., Braband A., Tolley L., Reimann A., Mittmann B., Lukhaup C., Steuerwald F. and Vogt G., 2003. Parthenogenesis in an outsider crayfish. Nature, 421, 806.

Schulz H.K., Gross H., Dümpelmann C. and Schulz R., 2009. Flusskrebse Deutschlands. In: Füreder L. (ed.), Flusskrebse: Biologie - Ökologie - Gefährdung, Veröffentlichungen des Naturhistorischen Museums Südtirol, 6, Folio Verlag, Bozen, Wien, 71-81.

Skurdal J. and Taugbøl T., 1994. Minimum size regulation as a tool in crayfish management practice. Nord. J. Freshwat. Res., 69, 144-148.

Skurdal J. and Taugbøl T., 2002. Crayfish of commercial importance - Astacus. In: Holdich D.M. (ed.), Biology of Freshwater Crayfish, Blackwell Science, Oxford, 467-510.

Soes D.M. and van Eekelen R., 2006. Rivierkraeften een opruuend problem? De Levende Natuur, 107, 56-59.

Swahn J.Ö., 2004. The cultural history of crayfish. Bull. Fr. Pêche Piscic., 372-373, 243-251.

Taugbøl T. and Johnsen S.I., 2006. NOBANIS - invasive alien species fact sheet - Pacifastacus leniusculus. Online database of the North European and Baltic Network on Invasive Alien Species - NOBANIS, www.nobanis.org.

Thies F., Garry J.M.C., Yaqoob P., Rerkasem K., Williams J., Shearman C., Gallagher P.J., Calder P.C. and Grimble F.R., 2003. Association of n-3 polyusaturated fatty acids with stability of atherosclerotic plaques: a randomised controlled trial. The Lancet, 361, 477-485.

Tricarico E., Bertocchi S., Brusconi S., Casalone E., Gherardi F., Giorgi G., Mastromei G. and Parisi G., 2008. Depuration of microcystin-LR from the red swamp crayfish Procambarus clarkii with assessment of food quality. Aquaculture, 285, 90-95.

Trouilhé M.C., Ricard F., Parinet B., Grandjean F. and Souty-Grosset C., 2003. Management of the whiteclawed crayfish (Austropotamobius pallipes) in western France: abiotic and biotic factors study. Bull. Fr. Pêche Piscic., 367, 97-114.

Trouilhé M.-C., Souty-Grosset C., Grandjean F. and Parinet B., 2007. Physical and chemical water requirements of the white-clawed crayfish (Austropotamobius pallipes) in western France. Aquatic Conserv. Mar. Freshw. Ecosyst., 17, 520-538.

Vinciguerra D., 1899. I gamberi d'acqua dolce in Italia. Annali di Agricoltura, 219, 1-25.

Vogt G., 2008. How to minimize formation and growth of tumours: Potential benefits of decapod crustaceans for cancer research. Intern. J. Cancer, 123, 2727-2734.

Wald G., 1967. Visual pigments of crayfish. Nature, 215, 1131-1133.

Wald G., 1968. The molecular basis of visual excitation. Nature, 219, 800-807.

Westman K., 1991. The crayfish fishery in Finland - its past, present and future. Finn. Fish. Res., 12, 187-216.

Westman K., Pursiainen M. and Westman P., 1990. Status of crayfish stock, fisheries, diseases and culture in Europe, Report of the FAO European Inland Fisheries Advisory Commission (EIFAC), Working Party of Crayfish, Helsinki.

Yerkes R.M. and Huggins G.E., 1903. Habit formation in the crawfish Cambarus virilis (Hagen). Harvard Psych. Stud., 1, 565-577. 